\title{
Effect of liquid cow manure amendment on dimethenamid persistence in a volcanic soil
}

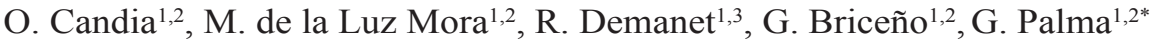 \\ ${ }^{I}$ Center of Plant, Soil Interaction and Natural Resources Biotechnology, Scientific and Technological \\ Bioresource Nucleus, Universidad de La Frontera, Avenida Francisco Salazar 01145, Casilla 54-D, Temuco, \\ Chile. ${ }^{2}$ Departamento de Ciencias Químicas y Recursos Naturales, Universidad de La Frontera, Casilla 54- \\ D, Temuco, Chile. ${ }^{3}$ Departamento de Producción Agropecuaria, Universidad de La Frontera, Casilla 54-D, \\ Temuco, Chile. *Corresponding author: gpalma@ufro.cl.
}

\begin{abstract}
The effect of liquid cow manure (LCM) on dimethenamid persistence was studied using amended soils with various stabilization times and LCM doses corresponding to specific field applications. Soils were amended with LCM doses equivalent to 100,000, 200,000, and 300,000 L ha-1. Dimethenamid (2-chloro-N-(2, 4-dimethyl3-thienyl]-N-[2-methoxy-1-methylethyl) acetamide) was applied in a field dose. The study was conducted under controlled conditions using an Andisol without the prior application of the herbicide and LCM. Respiratory activity, fluorescein diacetate (FDA) activity, and residual dimethenamid were measured within a specific time period. The respiratory activity and FDA studies showed that LCM-amended soils were stabilized after 20 days in incubation and displayed no significant differences after applying dimethenamid. The half-life $\left(t_{1 / 2}\right)$ of dimethenamid in soil was 28 days; however, in LCM-amended soils, the half-life ranged from 13 to 21 days. In the amended soil, the $t_{1 / 2}$ decreased significantly to 13 days in soils that contained the highest levels of LCM at 10 days of pre-incubation. The results show that both the dose and stabilization time of LCM-amended soils change the half-life of dimethenamid. Larger LCM doses are not recommended for field application. Dimethemanid should be applied 20 days after the soil amendment to increase dimethenamid efficacy.
\end{abstract}

Keywords: dimethenamid, liquid cow manure, Andisol, microbial respiration, persistence. 


\section{Introduction}

The growing demand for products of animal origin has resulted in a higher dairy plant production of slurry or liquid cow manure (LCM), which consists of excrement, urine, and washing water. LCM is generally stored in uncovered pits and is spread on pastures or soils that are subsequently used to sow maize for animal feed.

The application of LCM to agricultural soil is considered effective waste management option because of nutrient recycling and the presence of organic matter $(\mathrm{OM})$, which improves nutrient content, microbial biomass, and soil enzyme activity (Perucci et al., 2000; Dungan et al., 2003; Said-Pullicino et al., 2004). Various authors have reported on the effects of animal manure on the dissipation of herbicides (Sluszny et al., 1999; Moorman et al., 2001; Farenhorst et al., 2006; Briceño et al., 2007). An increase in biological activity resulting from a high amount of both stable soil organic matter and dissolved organic matter could have various effects on degradation, adsorption, and leaching herbicide processes (Topp et al., 1996; Perrin-Ganier et al., 2001; Albarrán et al., 2004).

In Southern Chile, LCM is applied to soils prior to planting the maize fodder crop (Salazar et al., 2003; Briceño et al., 2010) between August and October; however, the LCM that is applied is highly variable, containing up to $300,000 \mathrm{Lha}^{-1}$. Moreover, the amount of time required between the most current application of LCM and herbicide application is unknown. This practice may be responsible for the decrease in weed control that has been observed in some fields (Briceño et al. 2008; Aguilera et al., 2009). The evaluation of microbial respiration and FDA activity has been useful for evaluating the response of freshly amended soils after the application of pesticides (Perucci et al., 2000; Dungan et al., 2003).

Dimethenamid(2-chloro- $N$-(2,4-dimethyl3-thieny $1]-N$-[2-methoxy-1-methylethyl) acetamide) is a pre- plant and pre-emergence herbicide that was recently introduced in southern Chile as a gramineous and some dicot weed control in maize and soybean crops. This herbicide has a low persistence in soil, with a $t_{1 / 2}$ of 2043 days, depending on weather and soil conditions. It is highly soluble in water $\left(1174 \mathrm{mgL}^{-1}\right)$, is moderately adsorbed in soils (Koc 155) and is classified as potentially leachable (FOOTPRINT database, 2011). Research on the environmental behaviour of dimethenamid is limited, although is available since 1992. Studies performed by Crawford et al. (2002), show that a significant amount of dimethenamid remains as soil-bound residue. Studies carried out by Hladik et al. (2008) at various rivers in the United States show that dimethenamid in water sampled during the spring ranged from 2-67 ng L ${ }^{-1}$, with a 75\% occurrence rate.

The objective of this study was to determine the effects of the LCM dose and stabilization time of amended soils on dimethenamid degradation under controlled conditions in a volcanic soil. This research will contribute to specific development strategies within agricultural practices that aim to streamline LCM and herbicide use and minimize environmental impacts.

\section{Materials and methods}

The laboratory experiment was conducted in 2010 . The soil used in this study was an Andisol with a sandy loam texture from Southern Chile, termed the Vilcún series (Pachic Melanudands), from the town of General Lopez ( $38^{\circ} 41^{\prime}$ LS, $72^{\circ} 21^{\prime}$ LW, 200 m.a.s.l.). The annual rainfall is approximately $2,000 \mathrm{~mm}$ per year, and the average temperature is $15^{\circ} \mathrm{C}$. The soil was collected from a superficial layer to a depth of $20 \mathrm{~cm}$ and sieved through a 2-mm mesh. It contained no prior application of LCM or dimethenamid. The LCM was obtained from an open slurry pit located near the dairy plant. 
Dimethenamid (99\% purity) was supplied by SigmaAldrich Chemical Company, St Louis, MO. In the laboratory, $1.2 \mathrm{mg} \mathrm{kg}^{-1}$ dimethenamid was used, with the assumption that the herbicide is distributed at a depth of $20 \mathrm{~cm}$ and that the soil density is $0.75 \mathrm{~g} \mathrm{~mL}^{-1}$. This dose correlates to a field application of $1.5 \mathrm{~kg} \mathrm{ha}^{-1}$.

\subsection{Chemical analysis of LCM and soils}

The LCM analysis was performed according to the methodology of Peters et al. (2003) and with previous information from our research group (Briceño et al., 2008). Briefly, the $\mathrm{pH}$ and electrical conductivity (EC) were measured in non-diluted LCM. To estimate the dissolved organic carbon (DOC), the LCM was centrifuged and the supernatant was filtered, lyophilized, and analysed as a total organic carbon (EURO EA 3000 Elemental Analyzer). Dry matter (DM) was determined through water evaporation of the LCM at $70{ }^{\circ} \mathrm{C}$. Next, the OM content was estimated by finding the mass difference between the LCM and ash mass. Several chemical LCM characteristics were identified: DM $53.0 \mathrm{~g} \mathrm{~L}^{-1}$, EC $5.9 \mathrm{dS} \mathrm{m} \mathrm{m}^{-1}$, OM 71.1 $\mathrm{mg} \mathrm{kg}{ }^{-1}$, DOC $2140 \mathrm{mg} \mathrm{L}^{-1}, \mathrm{pH} 7.5$, and $\mathrm{N} 28.6 \mathrm{~g} \mathrm{~kg}^{-1}$. Soil samples were characterized from Briceño et al. (2008) based on methods described by Sadzawka et al. (2006) and are included in Table 1.

\subsection{Preparation of LCM-amended soils}

LCM was applied to soil in doses of $0,70,140$, and $200 \mathrm{~mL} \mathrm{~kg}^{-1}$, which are equivalent to field doses corresponding to 0, (D0), 100,000 (D100), 200,000 (D200) and 300,000 (D300) $\mathrm{L} \mathrm{ha}^{-1}$, respectively. The moisture of the non-amended and amended soils was adjusted to $70 \%$ of the field capacity and was also adjusted periodically by adding distilled water. Four kilograms of LCM-amended and non-amended soils were pre-incubated in the absence of light at $20^{\circ} \mathrm{C}$ without herbicide application in open polypropylene bags for each pre-incubation time (1, 10, 20, 30 and 60 days). For the $\mathrm{CO}_{2}$ evolution and FDA study, $500 \mathrm{~g}$ of each preincubated soil was spiked with $12 \mathrm{ml}$ of $50 \mathrm{mgL}^{-1}$ of dimethenamid aqueous solution and then thoroughly mixed. In the degradation study, a fraction of $1.5 \mathrm{~kg}$ of each pre-incubated soil was contaminated with 36 $\mathrm{mL}$ of the same dimethenamid solution. The dimethenamid dose corresponded to $1.2 \mathrm{mg} \mathrm{kg}^{-1}$, which was equivalent to the field dose. The studies were conducted three times, and values were measured with respect to the reference soil, which did not contain any herbicide application.

After the corresponding pre-incubation time, the soil samples were chemically characterized (Table 1) according to Sadzawka et al. (2006).

Table 1. Characterization of tested soil and LCM-amended soils at four pre-incubation times.

\begin{tabular}{llllllllllllll}
\hline & \multicolumn{1}{l}{ Day 1 } & \multicolumn{4}{c}{ Day 10 } & \multicolumn{3}{c}{ Day 20 } \\
\cline { 2 - 13 } & D0 & D100 & D200 & D300 & D100 & D200 & D300 & D100 & D200 & D300 & D100 & D200 & D300 \\
\hline pH & 5.3 & 5.5 & 5.7 & 6.1 & 5.3 & 5.3 & 5.8 & 5.4 & 5.3 & 5.8 & 5.3 & 5.2 & 5.7 \\
$\mathrm{OM}(\%)$ & 19 & 17 & 19 & 17 & 17 & 15 & 15 & 16 & 17 & 15 & 17 & 18 & 16 \\
$\mathrm{P}\left(\mathrm{mg} \mathrm{kg}^{-1}\right)$ & 27 & 28 & 29 & 29 & 25 & 26 & 27 & 27 & 28 & 28 & 28 & 29 & 29 \\
$\mathrm{~K}\left(\mathrm{mg} \mathrm{kg}^{-1}\right)$ & 188 & 391 & 430 & 782 & 422 & 461 & 668 & 508 & 500 & 703 & 520 & 559 & 798 \\
$\mathrm{DOC}\left(\mathrm{mg} \mathrm{kg}^{-1}\right)$ & 51 & 280 & 390 & 533 & 96 & 125 & 236 & 87 & 102 & 147 & 75 & 93 & 131 \\
$\mathrm{EC} 1: 5\left(\mu \mathrm{cm}^{-1}\right)$ & 217 & 360 & 574 & 680 & 314 & 475 & 516 & 366 & 460 & 508 & 330 & 493 & 542 \\
$\mathrm{C} / \mathrm{N} \mathrm{ratio}$ & 16.5 & 16.1 & 15.3 & 13.3 & 16.8 & 17.6 & 15.8 & 17.6 & 16.8 & 16.3 & 15.8 & 16.2 & 16.3 \\
\hline
\end{tabular}

LCM was applied on soil at equivalent doses of $0,100,000,200,000$ and 300,000 L ha ${ }^{-1}$ (D0, D100, D200, and D300, respectively). 


\subsection{Microbial respiration assay}

The respiration study was based on a method described by Alef (1995). Sub-samples consisting of 50 $\mathrm{g}$ of each soil were placed inside a $1 \mathrm{~L}$ sealed flask containing a vial with distilled water and a second vial with $10 \mathrm{~mL}$ of $\mathrm{NaOH} 0.5 \mathrm{M}$ to capture the $\mathrm{CO}_{2}$ released from the soil. The experiment was performed at $20^{\circ} \mathrm{C}$ in the absence of light. The vials containing the $\mathrm{NaOH}$ solution were sampled and replaced periodically for 60 days. The $\mathrm{CO}_{2}$ in the vials was determined with $0.5 \mathrm{M} \mathrm{HCl}$ using titration. The data were expressed as $\mathrm{C}-\mathrm{CO}_{2} \mu \mathrm{g} \mathrm{g}^{-1}$ soil.

\subsection{FDA assay}

The FDA hydrolytic activity assay was performed by measuring the release of fluorescein as described by Adam and Duncan (2001). One gram of each soil was incubated in a $50 \mathrm{~mL}$ conical tube containing $7.5 \mathrm{~mL}$ of $0.06 \mathrm{M}$ potassium phosphate buffer ( $\mathrm{pH}$ 7.2). The reaction was initiated by adding $0.1 \mathrm{~mL}$ of $1 \mathrm{mg} \mathrm{mL}^{-1}$ FDA solution, and then the solution was incubated at $30^{\circ} \mathrm{C}$ and shaken at $100 \mathrm{rpm}$ for $20 \mathrm{~min}$. At this time, the reaction was stopped by adding $7.5 \mathrm{~mL}$ of chloroform $/$ methanol $(2: 1 \mathrm{v} / \mathrm{v})$. The samples were then centrifuged for $10 \mathrm{~min}$, and the absorbance was measured at $490 \mathrm{~nm}$. The FDA activity was measured for 60 days after the dimethenamid application. The fluorescein concentration was calculated using a calibration curve generated with known FDA concentrations, and the data were expressed as FDA $\mu \mathrm{g} \mathrm{g}^{-1}$.

\subsection{Dimethenamid degradation assay}

In the degradation study, a fraction of $50 \mathrm{~g}$ of each soil was taken for 60 days after the dimethenamid treatment. The samples were stored at $-20^{\circ} \mathrm{C}$ until the her- bicide was extracted. The residual dimethenamid was determined for the HPLC analysis, and the herbicide concentration matched first-order kinetics (NkediKizza and Brown, 1998).

\subsection{Residual dimethenamid analysis}

Dimethenamid was extracted using a modified method proposed by Anderson et al. (2005). Ten grams of each soil sample was extracted with $10 \mathrm{~mL}$ of a mixture of methanol/water $(95 / 5 \mathrm{v} / \mathrm{v})$ and was then shaken at $200 \mathrm{rpm}$ for $1 \mathrm{~h}$ at $20^{\circ} \mathrm{C}$, followed by 30 min in an ultrasonic bath. The supernatant was collected, and this procedure was repeated three times. The combined supernatant extracts were centrifuged for $10 \mathrm{~min}$ and filtered through $0.45-\mu \mathrm{m}$ membranes (Millipore). The liquid extract was concentrated at $5 \mathrm{~mL}$ at $40^{\circ} \mathrm{C}$ in a rotary evaporator (Heidolph WV 2000). These extracts were then liquid-liquid extracted with $10 \mathrm{~mL}$ of hexane in a separating funnel, and this process was repeated 3 times. The hexane extract was dried in a rotary evaporator, and the sample was dissolved in $2 \mathrm{~mL}$ of methanol. The solution was filtered through a $0.22-\mu \mathrm{m}$ filter, and the residual herbicide was measured by HPLC, based on a method established by Crawford et al. (2002). The analysis was performed in HPLC (Merck Hitachi, model 3400) equipped with a UV detector at $210 \mathrm{~nm}$ on a Symmetry C18 column (Waters, $5 \mu \mathrm{m}, 250 \mathrm{~mm} \times 4.6 \mathrm{~mm}$ ). The mobile phase used acetonitrile/water (55- 45\%) at a flow rate of $1 \mathrm{~mL} \mathrm{~min}^{-1}$, and the injection volume was $20 \mu \mathrm{L}$.

\subsection{Data analysis}

The data were subjected to statistical analyses of variance (ANOVA), and all mean separations were determined using the Tukey test $(p \leq 0.05)$. 


\section{Results and discussion}

\subsection{Biological assessments}

Figure 1 shows that the LCM amendment had substantially increased the $\mathrm{CO}_{2}$ during the first day of incubation for soils that had been pre-incubated for one day. An increase in $\mathrm{CO}_{2}$ did not occur for other pre-incubation times that had the same impact; however, significant increases were observed in the initial production of $\mathrm{CO}_{2}$. During the first day of pre-incubation, the $\mathrm{CO}_{2}$ production was greater than $47 \mu \mathrm{g} \mathrm{C}-\mathrm{CO}_{2} \mathrm{~g}^{-1} \mathrm{~d}^{-1}$ in D0, and it increased 62, 128, and $232 \mu \mathrm{g} \mathrm{C}-\mathrm{CO}_{2} \mathrm{~g}^{-1} \mathrm{~d}^{-1}$ in D100, D200 and D300, respectively. After 30 days,
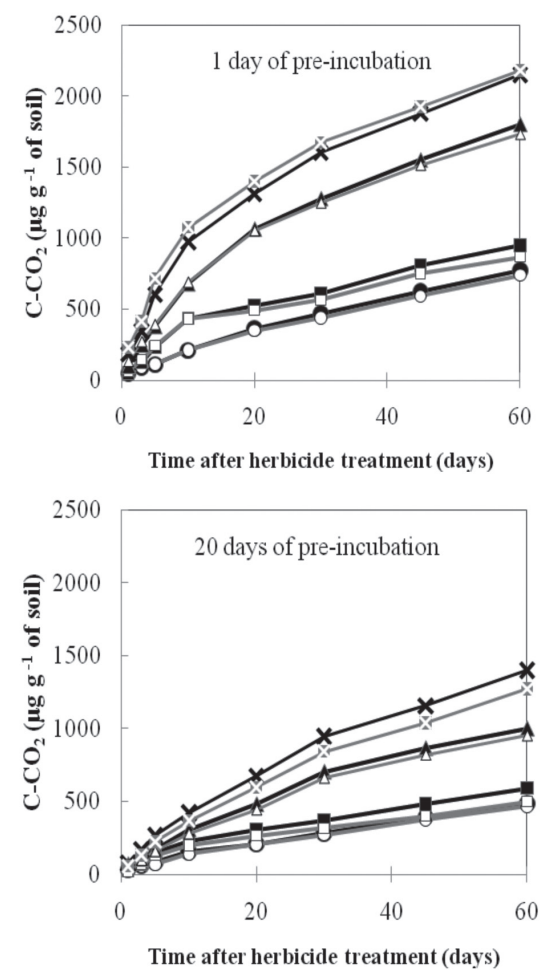

$$
\begin{array}{ll}
\text { D0 (T) } & -\mathrm{O} \text { D0 (C) } \\
\mathrm{D} 200(\mathrm{~T}) & -\triangle \mathrm{D} 200(\mathrm{C})
\end{array}
$$

$\mathrm{CO}_{2}$ evolution gradually decreased at $16 \mu \mathrm{g} \mathrm{C}-\mathrm{CO}_{2} \mathrm{~g}^{-1}$ $\mathrm{d}^{-1}$, and the total production of $\mathrm{C}-\mathrm{CO}_{2}$ was 440,565 , 1249 and $1673 \mu \mathrm{g} \mathrm{C}-\mathrm{CO}_{2} \mathrm{~g}^{-1}$ in D0, D100, D200 and D300, respectively. The results show that an increase in the LCM dose will significantly increase $\mathrm{CO}_{2}$ production, following the pattern D300 $>$ D200 $>$ D100 $>$ D0 . Gradually, during 30 days of pre-incubation treatment, $\mathrm{CO}_{2}$ production decreased until there were similar soil respiration levels, with the exception of D300, which has a significantly greater value. There were no significant observed differences in $\mathrm{CO}_{2}$ production with respect to the controls when dimethenamid was applied in the LCM treatments.
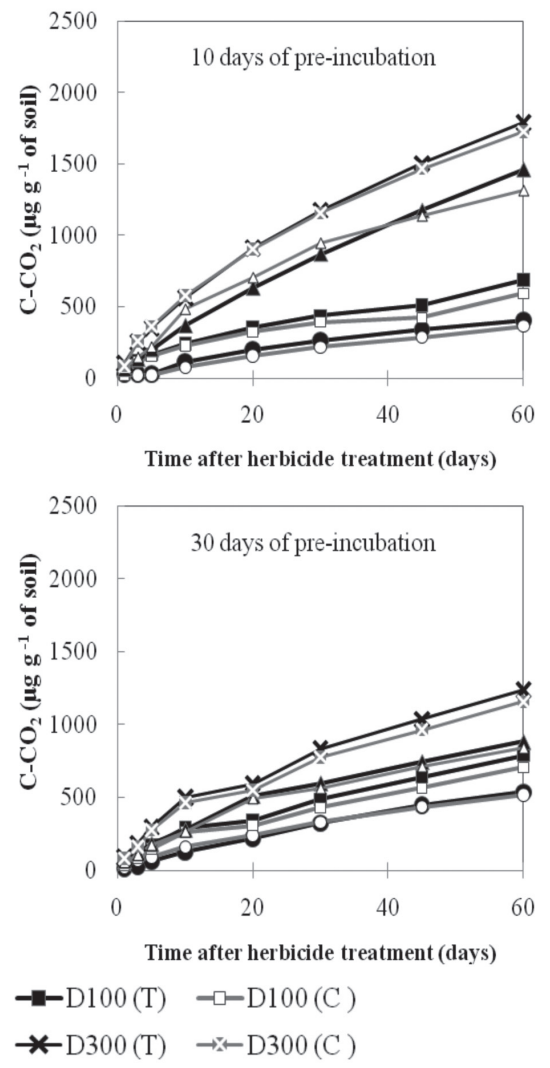

Figure 1. Respiratory activity in soil (D0) and LCM-amended soils (D100, D200, D300) at four pre-incubation times. T: with dimethenamid, $\mathrm{C}$ : without dimethenamid. 
Amended soils were characterized by a large amount of fresh organic matter available for micro-organisms, which increased with a greater LCM dose (Table 1). Figure 2 shows the relationship between the decreasing dissolved organic carbon and respiration rate levels.
The initial $\mathrm{CO}_{2}$ increase is essentially a result of the rapid biodegradation of the available carbon (Reinertsen et al., 1984; Ajwa and Tabatabai, 1994, Plaza et al., 2004.)

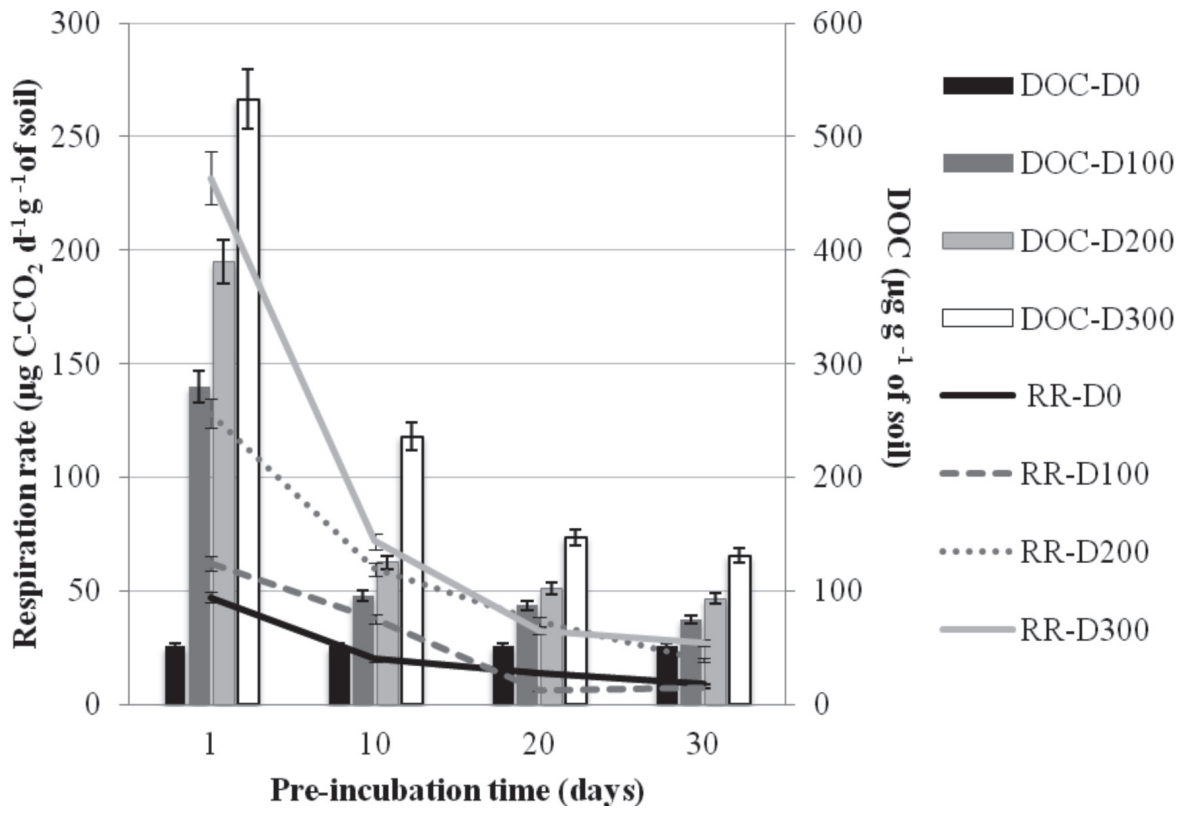

Figure 2. Relation between respiration rates (RR) and dissolved organic carbon content (DOC) in soil (D0) and LCM-amended soils (D100, D200, D300) at four pre-incubation times. Error bars denote the S.E. of the mean (n=3).

Enzymatic FDA activity is a sensitive and non-specific tool for representing the hydrolytic activity of soil micro-organisms. The FDA activity in each LCMamended soil at different pre-incubation periods is presented in Table 2. FDA hydrolysis indicated high variability in the time between treatments. A statistical analysis was performed for each pre-incubated soil at each evaluation time. No significant differences were found in the LCM-amended soils when dimethenamid was applied; however, the application of LCM significantly increased FDA activity, with the highest dose of LCM observed for pre-incubated soils at 1,10 and 20 days. The average FDA activity of soil was approximately $440 \mu \mathrm{g} \mathrm{g}^{-1}$ fluorescein. For D300, in the pre-incubated amended soils for 1, 10, 20 days, the FDA activity was approximately 460, 510 and $580 \mu \mathrm{g} \mathrm{g}^{-1}$ fluorescein, respectively; however, decreased after 20 days. For the 30 pre-incubated soils, FDA activity did not show any significant difference among treatments, except for D300, which had an average of $490 \mu \mathrm{g} \mathrm{g}^{-1}$ fluorescein. Similar results have been obtained from other authors who have shown that an increase in enzyme activity is related to the organic manure application and amendments (Perucci, 1992; Serra-Wittling et al. 1996). 
Table 2. FDA activity in soil and LCM-amended soils at four pre-incubation times.

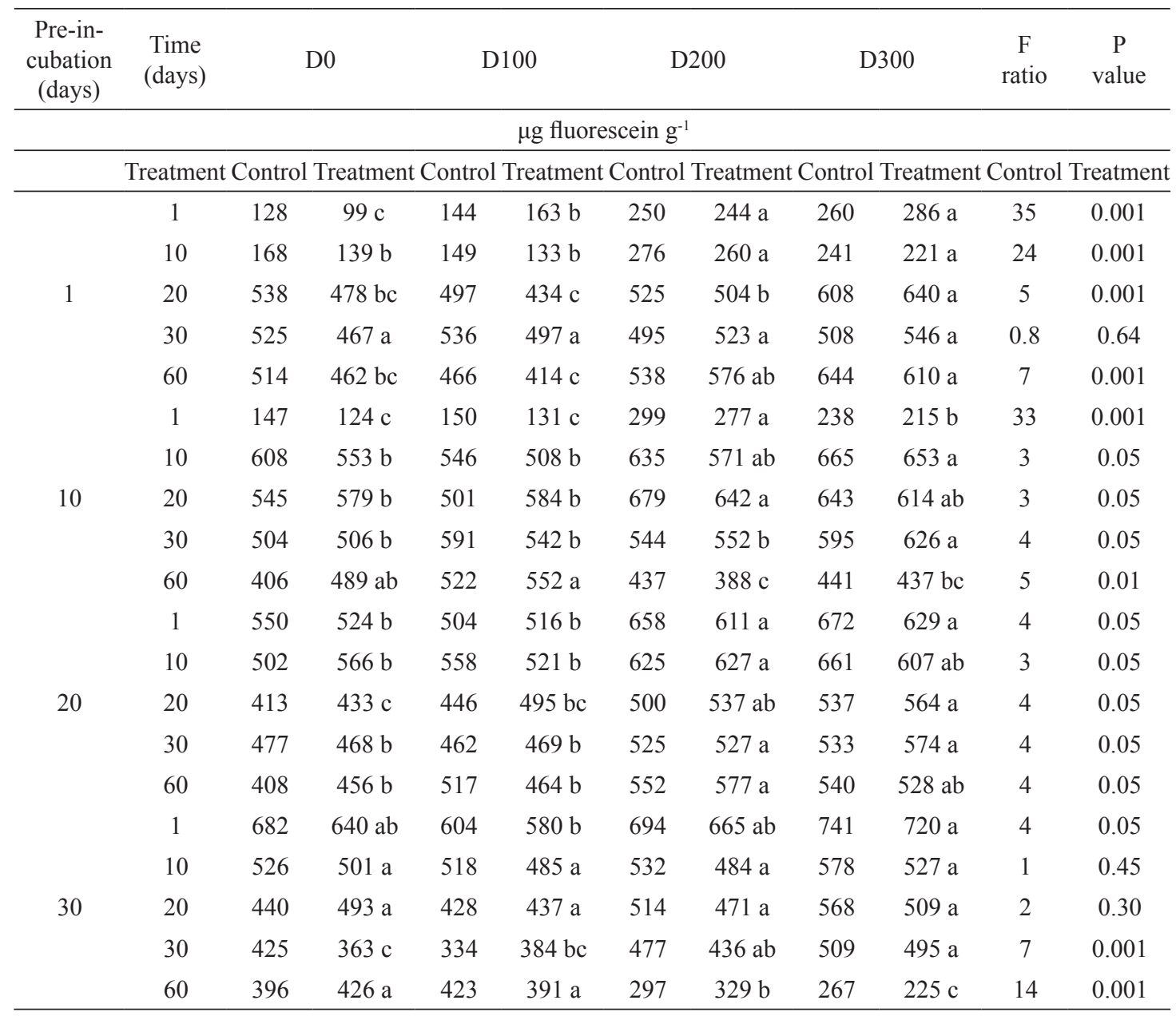

LCM was applied on soil at equivalent doses of 0, 100,000, 200,000 and 300,000 $\mathrm{L} \mathrm{ha}^{-1}$ (D0, D100, D200, and D300, respectively). Different letters indicate significantly different values in the same row; ANOVA with Tukey test $(p<0.05)$.

Biological assays (microbiological respiration and FDA measurement) were used to determine the stabilisation of amended soils in comparison to non-amended soil. The results show that amended soils require more than 20 days to stabilise, which is the minimum time period required between LCM and herbicide application.
Both microbial respiration and enzymatic activity indicated that dimethenamid application at the recommended field dose did not display a significant difference among LCM treatments. This is most likely due to the dimethenamid is part of a family of herbicides that are not considered to be completely mineralisable (Stamper and Tuovinen, 1998; De Schrijver and De Mot, 1999). 


\subsection{Dimethenamid degradation in LCM-amended soils}

The results of this study are shown in Figure 3. For each evaluation period, the 1 day pre-incubated soils, D200 and D300, did not significantly differ in residual concentration of dimethenamid. For example, approximately $60 \%$ of the dimethenamid was degraded at 10 days and $90 \%$ was degraded at 60 days. For soils pre- incubated for 10 days, D200 and D300 degrade at 92 and $97 \%$ of dimethenamid, respectively. This explains the effect of LCM dose and pre-incubation time in dimethenamid persistence compared to soil with $80 \%$ dimethenamid degradation. D100 amended soil has a behaviour similar to D0. After 20 days of pre-incubation, the degradation of dimethenamid is similar for all treatments at approximately $80 \%$, except for D300, which undergoes $90 \%$ degradation.
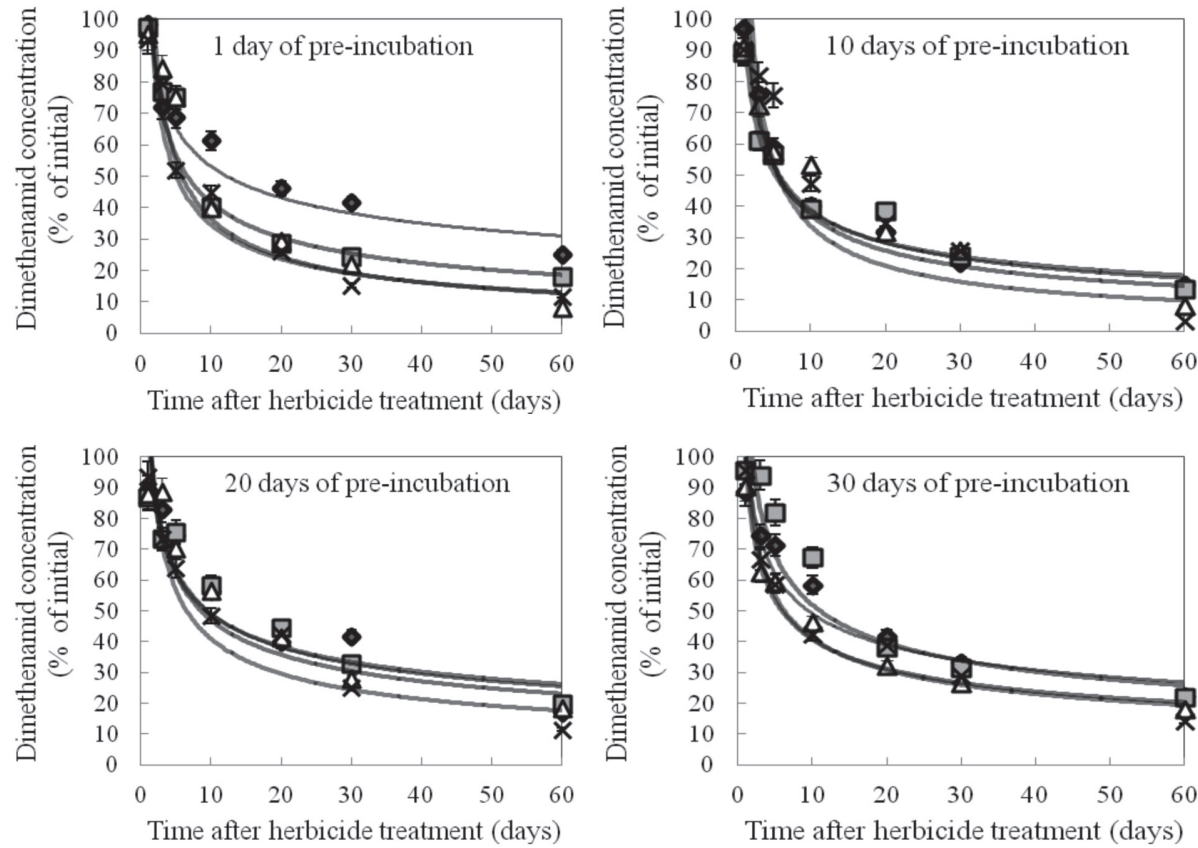

$\bullet$ D0 $\quad$ 口D100

$\Delta \mathrm{D} 200 \quad \times \mathrm{D} 300$

Fig. 3. Residual dimethenamid in soil (D0) and LCM-amended soils (D100, D200, D300) at four pre-incubation times. Error bars denote the S.E. of the mean $(n=3)$.

The $t_{1 / 2}$ of dimethenamid was significantly smaller for D200 and D300 in pre-incubated amended soils from days 1-20 (Table 3) and ranged from 13 to 21 days. For D0 and amended soils pre- incubated for 30 days, the dimethenamid half-life was approximately 27 days. 
Table 3. Dimethenamid half-life $\left(t_{1 / 2}\right)$ in soil and LCM-amended soils at four pre-incubation times.

\begin{tabular}{ccccc}
\hline Pre-incubation(days) & Soil & $\mathrm{k}\left(\right.$ day $\left.^{-1}\right)$ & $\mathrm{t}_{1 / 2}($ day $)$ & $\mathrm{R}^{2}$ \\
\hline 1 & D0 & 0.025 & $28 \mathrm{a}^{\mathrm{b}}$ & 0.92 \\
& $\mathrm{D} 100$ & 0.028 & $25 \mathrm{a}$ & 0.79 \\
$\mathrm{D} 200$ & 0.040 & $18 \mathrm{~b}$ & 0.93 \\
& D300 & 0.035 & $20 \mathrm{~b}$ & 0.84 \\
\multirow{3}{*}{10} & D0 & 0.025 & $28 \mathrm{a}$ & 0.86 \\
& D100 & 0.029 & $24 \mathrm{ab}$ & 0.91 \\
& D200 & 0.038 & $18 \mathrm{~b}$ & 0.98 \\
& D300 & 0.055 & $13 \mathrm{c}$ & 0.98 \\
& D0 & 0.025 & $28 \mathrm{a}$ & 0.95 \\
& D100 & 0.025 & $28 \mathrm{a}$ & 0.96 \\
& D200 & 0.028 & $25 \mathrm{a}$ & 0.91 \\
& D300 & 0.034 & $21 \mathrm{~b}$ & 0.96 \\
& D0 & 0.025 & $28 \mathrm{a}$ & 0.93 \\
& D100 & 0.027 & $26 \mathrm{a}$ & 0.89 \\
& D200 & 0.025 & $28 \mathrm{a}$ & 0.86 \\
& D300 & 0.028 & $24 \mathrm{ab}$ & 0.91 \\
\hline
\end{tabular}

LCM was applied on soil at equivalent doses of 0, 100,000, 200,000 and 300,000 $\mathrm{L} \mathrm{ha}^{-1}$, (D0, D100, D200, and $\mathrm{D} 300$, respectively). $\mathrm{K}$, the degradation rate constant is based on first order degradation model. Different letters indicate significantly different values of each treatment; ANOVA with Tukey test $(p<0.05)$.

\section{Conclusions}

Our results indicate that dimethenamid application to the soil must be after the liquid cow manure reaches the stabilization step. Furthermore, our results suggest that dimethenamid degradation is significantly greater when larger liquid cow manure (LCM) doses are applied. This degradation is also affected by the period of pre-incubation time in amended soils due to microbial activity. Therefore, based on this study, dimethenamid application is recommended when the LCM-amended soils are stabilised microbiologically, which, as in non-amended soils, occurs at least after 20 days from LCM application.

\section{Acknowledgements}

This study was financed by the projects FONDECYT 1070568 and DIUFRO DI10-1002.

\section{References}

Adam, G., Duncan, H. 2001. Development of a sensitive and rapid method for the measurement of total microbial activity using fluorescein diacetate (FDA) in a range of soils. Soil Biol. Biochem. 33, 943-951.

Aguilera, P., Briceño, G., Candia M., Mora M., Demanet R., Palma, G. 2009. Effect of dairy manure rate and the stabilization time of amended soils on atrazine degradation. Chemosphere 77, 785-790. 
Ajwa, H., Tabatabai, M. 1994. Decomposition of different organic materials in soils. Biol. Fertil. Soils 18, 175-182.

Albarrán, A., Celis, R., Hermosin, M.C., Lopez-Pineiro, A., Cornejo, J. 2004. Behaviour of simazine in soil amended with the final residue of the olive-oil extraction process. Chemosphere, 54, 717-24.

Alef, K. 1995. Estimation of soil respiration. In: Alef, K., Nannipieri, P. (Eds.), Methods in Applied Soil Microbiology and Biochemistry. Academic Press, London, 464-467.

Anderson, K., Basile, J., Johnson, E. 2005. Analytical method for dimethenamid-P in selected raw agricultural commodities by gas chromatography with electron capture detection. J. AOAC Int. 88, 1428-1432.

Briceño, G., Palma, G., Durán, N. 2007. Influence of organic amendment on the biodegradation and movement of pesticides. Crit. Rev. Environ. Sci. and Technol. 37, 233-271.

Briceño, G., Demanet, R., Mora, ML., Palma, G. 2008. Effect of liquid cow manure on andisol properties and atrazine adsorption. J. Environ. Qual. 37, 1519-1526.

Briceño, G., Jorquera, M., Demanet, R., Mora, ML., Durán, N., Palma, G. 2010. Effect of cow amendment on atrazine dissipation and bacterial community structure in a agricultural Andisol. Sci. Total Environ. 408, 2833-2839.

Crawford, J., Sims, G., Simmons, F., Wax, L., Freedman, D. 2002. Dissipation of the herbicide [14C] dimethenamid under anaerobic conditions in flooded soil microcosms. J. Agric. Food Chem. $50,1483-1491$.

De Schrijver, A. and De Mot, R. 1999. Degradation of pesticides by actinomycetes. Crit. Rev. Microbiol. 25, 85-119.
Dungan, R.S., Ibekwe, A.M., Yates, S.R. 2003. Effect of propargyl bromide and 1,3-dichloropropene on soil microbial communities. FEMS Microbiol. Ecol. 43, 75-87.

Farenhorst, A., Reimer, M., Londry, K., Saiyed, I. 2006. 2, 4-Dichlorophenoxy acetic acid mineralization in amended soil. J. Environ. Sci. Health B. 41, 509-522.

FOOTPRINT DATABASE. http://sitem.herts.ac.uk/ aeru/footprint/en/ (Visited on August 20th of 2011).

Hladik, M., Bouwer, E., Roberts, L. 2008. Neutral degradates of chloroacetamide herbicides: Occurrence in drinking water and removal during conventional water treatment. Water Res. 42, 4905-4914.

Moorman, T., Cowan, J., Arthur, E., Coats, J. 2001. Organic amendments to enhance herbicide biodegradation in contaminated soils. Biol. Fertil. Soils 33, 541-545.

Nkedi-Kizza, P., Brown, K.D. 1998. Sorption, degradation and mineralization of carbaryl in soils for single pesticide and multiple pesticide systems. J. Environ. Qual. 27, 1318-1324.

Perrin-Ganier, C., Schiavon, F., Morel, J.L., Schiavon, M. 2001. Effect of sludge-amendment or nutrient addition on the biodegradation of the herbicide isoproturon in soil. Chemosphere 44, 887-92.

Perucci, P. 1992. Enzyme activity and microbial biomass in a field soil amended with municipal refuse. Biol. Fertil. Soils 14, 54-60.

Perucci, P., Dumontet, S., Bufo, S., Mazzatura, A., Casucci, C. 2000. Effects of organic

amendent and herbicide treatment on soil microbial biomass. Biol. Fertil. Soils 32, 17-23.

Peters, J., Combs, S.M., Hoskins, B., Jarman, J., Kovar, J., Watson, M., Wolf, A., Wolf, N. 
2003. Recommended Methods of Manure Analysis. University of Wisconsin Cooperative Extension Publication A3769. University of Wisconsin Cooperative Extension, Madison, WI.

Plaza, C., Hernández, D., García-Gil, J., Polo, A. 2004. Microbial activity in pig slurry-amended soils under semiarid conditions. Soil Biol. Biochem. 36, 1577-1585.

Reinertsen, S.A., Elliott, L.F., Cochran, V.L., Campbell, G.S. 1984. The role of available $\mathrm{C}$ and $\mathrm{N}$ in determining the rate of wheat straw decomposition. Soil Biol. Biochem. 16, 459-464.

Sadzawka, A., Grez, R., Carrasco, M., Mora, ML. 2006. Método de análisis recomendados para los suelo Chilenos. Comisión de Normalización y Acreditación Sociedad Chilena de la Ciencia del suelo.

Said-Pullicino, D., Gigliotti, G., Vella, A. 2004. Environmental fate of triasulfuron in soils amended with municipal waste compost. J. Environ. Qual. 33, 1743-1751.
Salazar,F., Dumont, J., Santana, M., Pain, B., Chadwick, D. Owen, E. 2003. A surver of dairy effluent management in the south of Chile, Arch. Med. Vet. 34, 215-225.

Serra-Wittling, C., Hounot, S., Barriuso, E. 1996. Modification of soil water retention and biological properties by municipal solid waste compost. Compost Sci. Util. 4, 44-52

Sluszny, C., Graber, E., Gerstl, Z. 1999. Sorption of s-triazine herbicides in organic matter amendment soils: fresh and incubated systems. Water Air Soil Pollut. 115, 395-410.

Stamper, D., and Tuovinen, O. 1998. Biodegradation of the acetanilide herbicides alachlor, metolachlor and propachlor. Crit. Rev. Microbiol. 24, 1-10.

Topp, E., Tessier, L., Gregorich, E. 1996. Dairy manure incorporation stimulates rapid atrazine mineralization in an agricultural soil. Can. J. Soil Sci. 76, 403-409. 
